ELORE (ISSN 1456-3010), vol. 19 - 2/2012.

Julkaisija: Suomen Kansantietouden Tutkijain Seura ry.

[http://www.elore.fi/arkisto/2_12/haapoja.pdf]

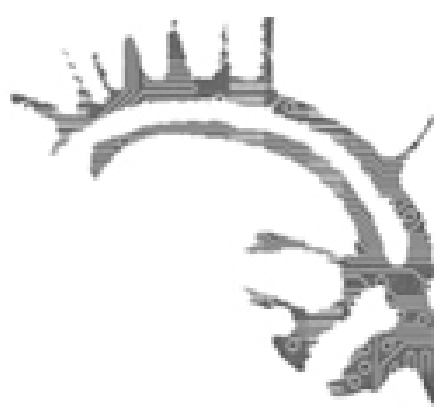

\title{
KIRJA-ARVIO
}

\section{PYHÄN URHON AIDOT ELÄMÄT}

HEIMO, ANNE, HOVI, TUOMAS, VASENKARI, MARIA (toim.) 2012: Pybä Urho. Fakeloresta folkloreksi. St Urho. From fakelore to folklore. Folkloristiikan julkaisuja 2. Turku: Turun yliopisto. 155 sivua.

\section{Heidi Haapoja}

Turun yliopiston kulttuurintutkijat ovat tarttuneet aiheeseen, joka suhteellisen erikoisten mutkien kautta yhdistää amerikansuomalaisia yhteisöjä ja Turun yliopiston kulttuurien tutkimuksen opiskelijoita: Pyhän Urhon kvasimyyttiin ja sen ympärille syntyneisiin ilmiöihin. Artikkelikokoelma Pyhä Urho. Fakeloresta folkloreksi luotaa 1950-luvulla amerikansuomalaisten keskuudessa syntynyttä Pyhän Urhon perinnettä sekä 1980-luvulla aloitetun turkulaisen opiskelijaperinteen juuria, luonnetta ja näiden kahden ilmiön yhtymäkohtia.

Pyhä Urho oli alun perin amerikansuomalaisten keskuudessa kiertänyt pila, vastine irlantilaisten siirtolaisten Pyhälle Patrickille. Tarina Urhosta, joka ajaa heinäsirkat (tai joidenkin lähteiden mukaan sammakot) pois Suomesta pelastaakseen viinirypälesadon, levisi viime vuosisadan puolivälissä amerikansuomalaisten yhteisöissä nopeasti. Tarinan keksijästä ei ole varmuutta, mutta rouva Gene McCavicin tiedetään luoneen sittemmin suosituksi tulleen laulun, Ode to St Urhon. Oodin sanat ovat fingliskaa, englannin ja suomen sekoitusta, ja sen iskeviä sanoja täydentävät riimit: "[...] He kot tall and trong from feelia sour / Unt ate kala moyakka effery hour. / Tat's why tat kuy could sase tose peetles / What krew as thick as chack bine neetles [..]" (Hän [Urho] kasvoi pitkäksi 
ja vahvaksi syötyään viiliä / hän söi myös kalamojakkaa [kalapataa] joka tunti / Sen vuoksi tämä kaveri pystyi jahtaamaan kuoriaisia / jotka kasvoivat yhtä paksuiksi kuin banksinmännyn neulaset") (s. 65, suomennos allekirjoittaneen).

Nykyään amerikansuomalaiset järjestävät vuosittain Pyhän Urhon juhlia, kulkueita, urheilu- ja kauneuskilpailuita. Juhlinnassa sekoittuvat amerikkalaiset, suomalaiset, amerikansuomalaiset ja muiden siirtolaisryhmien tavat, toimintamallit ja esimerkiksi ruokaperinteet. "Pyhimystarinan" vastaanotto on ollut kuitenkin läpi vuosien ristiriitaista: osa amerikansuomalaisista on kokenut tällaisen "keksityn perinteen" epäaidoksi, pötypuheeksi ja kulttuurin taantumiseksi.

Turun yliopistoon Pyhä Urho saapui eräänlaisena metatason kokeiluna 1980-luvun lopulla. Kulttuurin tutkimuksen opettajat Hannu-Pekka Huttunen ja Lassi Saressalo halusivat omien sanojensa mukaan kokeilla perinteen luomista: "Voitaisiinko Suomeen, Turkuun tai edes Fennicumiin luoda uusi traditio? Millainen sen tulisi olla, kenestä tulisi perinteenkannattaja (jotka olivat myös kovasti esillä etenkin folkloristisessa keskustelussa), millainen olisi perinneyhteisö?” (s. 107). Kokeilu päätettiin toteuttaa Urhosta kertovan näytelmän muodossa, ja sittemmin aina uudet opiskelijapolvet ovat toteuttaneet sen vuodesta toiseen. Kulttuurien tutkimuksen opiskelijajärjestöjen perinteisiin on myös vakiintunut Pyhän Urhon päivän iltajuhla, ja näytelmästä on tullut eräänlainen uusien opiskelijoiden initaatioriitti.

\section{Pyhä Urho ON PERINNetTä}

Käsillä oleva artikkelikokoelma on aiheeltaan varsin mielenkiintoinen ja inspiroiva. Perinteen, jatkuvuuden ja kollektiivisuuden olemuksien tutkiskelu ja suoranainen leikittely näillä teemoilla ovat kutkuttavia. Artikkeleissa pohditaan esimerkiksi keksityn perinteen ajatusta, ja Eric Hobsbawmin Terence Rangerin kanssa lanseeraama invented tradition -käsite vilahtaa teksteissä taajaan. Kirjoittajat ovat sekä tutkijoita että muiden alojen asiantuntijoita: suomenkieliset artikkelit ovat pääosin Turun yliopiston henkilökunnan käsialaa, kun taas englanninkielisten artikkelien taustalla on laajempi kirjo eri aloja edustavia henkilöitä.

Pekka Hakamiehen artikkeli avaa teoksen syvällisellä pohdinnalla folkloren kollektiivisuudesta ja sen tunnistamisesta erityisesti nykypäivän kulttuurissa. Samalla Hakamies tiivistää koko kirjan pääargumentin seuraavasti:

Amerikansuomalaisten ja lopulta Turun yliopiston folkloristiikan opiskelijoiden Pyhän Urhon perinne on syntynyt kuten muukin folklore: on ollut tarve yhteisöllisyyden ilmaisuun, ja sitä varten on kehitetty sopiva kertomus. Ei ole tärkeää, kuka sen on alun perin tehnyt, kun kertomus ja sen pohjalta muotoutunut näytelmä ovat olleet riittävän kiinnostavia, että ryhmä on ottanut ne omakseen ja ruvennut toistamaan niitä yhä uudelleen oman yhteisönsä tunnuksena ja artikulaationa. (s. 23-24.)

Artikkelikokoelma pyrkii olemaan todisteena (hieman leikkimielisellä otteella) folk- 
loren läsnä olevuudesta tässä jokapäiväisessä, ympärillä pyörivässä kulttuurissa. Kuten artikkeleissa todetaan, on amerikansuomalaisten ja yhtälailla turkulaisten opiskelijoiden ollut välillä vaikeaa nähdä Urhon päivän viettoa perinteenä, folklorena, ja sellaisenaan arvokkaana. Kirjan viimeisessä ja samalla myös kokoelman kiinnostavimmassa artikkelissa Tuomas Hovi pohtii, miten tällaista ilmiötä voi lähestyä teoreettisesta näkökulmasta. Hovi tuo esiin erilaisia folkloristiikan tutkimushistoriassa tunnettuja lähestymistapoja ja purkaa Urho-perinnettä näiden kautta. Hän esittelee fakeloren, folklorismin ja folkloreprosessin käsitteet ja hylkää niistä ainakin kaksi ensimmäistä Pyhän Urhon analyysivälineinä. Epäaitoa perinnettä tarkoittava fakelore on käsitteenä vanha ja varsin arvottava, ja Hovi huomauttaa, että fakeloreksi leimattu perinne saattaa jatkaa elämäänsä niin sanottuna aitona ja jaettuna perinteenä. Folklorismi taas viittaa kontekstistaan irrotetun perinteen kaupallistamiseen, mikä ei sekään kuvaa kovin kauaskantoisesti Pyhän Urhon tapaisia ilmiöitä.

Lauri Hongon folkloreprosessia (ks. Honko 1990) Hovi ei täysin tyrmää näkökulmana, sillä se tarjoaa suuntaa antavan mallin tutkia Pyhän Urhon kaltaista perinnettä. Paljon keskustelua herättäneen folkloreprosessiteorian mukaan perinnetuotteella on kaksi elämää, joista ensimmäinen on "perinne aidossa elinympäristössään" ja toinen "perinneaineiston ylösnousemus arkiston tai muun säilytyspaikan kätköstä" (Honko 1990, 104-119). Hovi puntaroi Amerikassa ja Turussa esiintyvää ilmiötä Honkoa mukaillen sekä "ensimmäisen" että "toisen elämän" näkökulmasta ja löytää molemmista folkloreprosessimallin elämien limittäisyyttä. Olennaista mallissa on, ettei se arvota elämien esiintymiä keskenään: jokainen elämä on tutkimuskohteena arvokas. Hovin, kuten muidenkin kirjoittajien, lopputulos onkin se, että Pyhän Urhon suhteen on turha puhua epäautenttisuudesta. Tämä ei ole hedelmällistä, sillä sellaisenaan, omanlaisenaan ilmiönä, Pyhä Urho luo ja vahvistaa yhteisöllisyyttä ja identiteettiä molemmissa kirjassa esitellyissä konteksteissa. Merkittävää on perinteen käyttö ja läsnäolo.

\section{LOPUKSI}

Käsillä olevalla artikkelikokoelmalla on varsin raflaava nimi, joka ensi kuulemalta on hieman hämmentävä. Fakeloresta puhuminen tuntuu selkeältä tuulahdukselta menneiltä vuosikymmeniltä! Kuten yllä on esitelty, nimivalinta aukeaa kuitenkin kirjaa lukiessa erityisesti Hovin artikkelin ja näkökulmavalintojen myötä, ja onhan se toki alkusointuineen varsin iskevä.

Kokoelma on sellaisenaan hieman epätasainen, sillä siinä limittyvät suhteellisen populaarit ja enemmän suurelle yleisölle suunnatut artikkelit, tieteelliset pohdinnat ja muistelmatyyppiset kirjoitukset. Teos lienee paikallaan esimerkiksi juuri Turun yliopiston kulttuurin tutkimuksen opiskelijoiden ensimmäisinä peruskurssilukemistoina, sillä helposti lähestyttävänä, esimerkeiltään värikkäinä ja perinteen olemusta hyvin konkreettisella tasolla käsittelevänä se herättää varmasti monessa lukijassa vastakaikua. 
Heidi Haapoja: Pyhän Urhon aidot elämät

\section{KirJallisuUS}

HOBSBAWM, ERIC \& RANGER, TERENCE (toim.) 1983: The Invention of Tradition. Cambridge: Cambridge University Press.

HONKO, LAURI 1990: Folkloreprosessi. - Sananjalka 32.

Filosofian maisteri, musiikin kandidaatti Heidi Haapoja tekee väitöskirjaa Helsingin yliopiston folkloristiikan oppiaineessa nykyrunolaulusta. 